\title{
An apocalyptic agenda for mission in our time
}

Author:
Arnold M. Meiring ${ }^{1}$
Affiliation:
'Department of Religious
Studies, Faculty of Theology
and Religion, University
of Pretoria, Pretoria,
South Africa
Corresponding author:
Arnold Meiring,
arno@universiteitsoord.co.za
Dates:
Received: 01 Sept. 2020
Accepted: 13 Oct. 2020
Published: 17 Dec. 2020
How to cite this article:
Meiring, A.M., 2020, 'An
apocalyptic agenda for
mission in our time', Verbum
et Ecclesia 41(1), a2144.
https://doi.org/10.4102/
ve.v41i1.2144
mobile device
to read online.
Copyright:
C) 2020. The Authors.
Licensee: AOSIS. This work
is licensed under the
Creative Commons
Attribution License.

Addressing the interest in missional theology and responding to the recent coronavirus disease 2019 (COVID-19) pandemic, this research developed an apocalyptic missional theology for our time. Whilst the Second World War inspired an exploration of the eschatological dimensions of mission, it was argued that apocalyptic theology adds a much needed perspective on mission. In addition to replying to the pandemic, apocalyptic missiology proved to be well suited to speak about the challenges for the Church in South Africa, and introduces African modes of thinking to missiology. This study comprised a qualitative literature research method that traced the history of eschatology and apocalyptic in missional thinking (summarised apocalyptic theology), demonstrated that apocalyptic theology contributes to current missiology, and finally developed an apocalyptic agenda for the mission. The research found that apocalyptic offers new ways of speaking about God that challenges contemporary powers and power structures, and presents prophetic and ethical ways for the church to participate in the Missio Dei. Apocalyptic extends a more universal future that includes all peoples and creation, and it provides believers with a new identity and comfort in our time. In conclusion, apocalyptic theology was found to enrich missional thinking, contributing hope and joy to the Christian message.

Intradisciplinary and/or interdisciplinary implications: This article suggested that apocalyptic theology adds new dimensions to missional theology, enriching the traditional discourse. It used the insights of biblical and religious studies, and applied it to missiology, as well as to systematic and practical theology.

Keywords: apocalyptic; eschatology; hope; mission; revelation; comfort; identity; ethics.

\section{Introduction: Apocalypse now!}

The recent coronavirus disease 2019 (COVID-19) pandemic awakened apocalyptic language and images in the public imagination. Some have visions of World War Z-like apocalypses that may occur when humankind's exploitation of our natural world finally turns against us (Olivier 2020). In addition, religious conspiracy theorists warn that the 'Fourth Seal' of the Book of Revelations has been opened and that pestilence has been unleashed on the earth (Kettley 2020). Even seemingly phlegmatic researchers turned to apocalyptic language to express their fears and concerns (Okereke \& Nielsen 2020).

Apocalyptic has for centuries been downplayed in mainline churches (Bosch 1991:175). Still, there were times when apocalyptic was popular. Around the Second World War, eschatological and apocalyptic thinking gave hope and purpose to theologians and missiologists alike. At the Tambaram Missionary Conference in 1938, the German missiologists Walter Freytag and Karl Hartenstein, together with their Dutch counterpart Hendrik Kraemer, added a minority report to the conference's findings, emphasising - in light of the looming war in Europe - the radical eschatological dimensions of the kingdom of God, in opposition to the optimistic Social Gospel message of the majority report (Meiring 1968:20-24).

After the Second World War, the eschatological motive for mission gained momentum, initially in continental Europe and later amongst the Anglo-Saxon theologians. At the meetings of the World Council of Churches in Amsterdam in 1948 (Evanston 1954; Willingen 1952), the emphasis on eschatology in the discussions and findings was evident (Meiring 1968:20-24).

Although the British and American missiologists were relatively late in accepting the importance of apocalyptic thinking (mostly falling back on traditional ideas about mission), a number of theologians joined the eschatological chorus. In the lead was Max Warren, who had already since 1948 developed a 'Theology of Expectancy' that aimed 'to do justice to the eschatological thinking which sees "the end" as still to come, (which) is necessary if Christians are going to respond to 
the apocalyptic challenge of our day'1 (Warren 1947:155). Warren's famous quote became a rallying cry for missiologists and church leaders in the post-war years (Warren 1947):

... [A]ny effective prosecution of the Church's primary task of evangelism in the world of our time must depend upon the nature of its hope. What is more, the nature of that hope will largely determine the character of that hope. (p. 57)

Eschatological and apocalyptic perspectives were developed further in theologies of hope, developed by, amongst others, Hans Margull, Jürgen Moltmann and Oscar Cullmann (Bosch 1991:176). The interest in both eschatology and apocalyptic continued into the 1970s and the 1980s, in South Africa as well. In 1978, the South African Old Testament Society's annual meeting was specifically dedicated to the issue of apocalyptic.

Then, at the turn of the century, interest in apocalyptic theology seemed to wane, except for the monumental work, The Open Heaven, by Rowland (1982) that challenged others to respond.

In South African missiological thinking, some attention had been given to the meaning of eschatology for missionary thinking. In 1960, J.A. Lombard devoted his inauguration lecture as a professor at the University of South Africa to the topic of Sending as daad van die Christelike hoop (Mission as an act of Christian hope). However, interest in the value of apocalyptic thinking for mission was virtually non-existent. König and Wielenga correctly show that David Bosch, for example, neglected the apocalyptic when he developed his missiology. In his doctoral thesis (Die Heidenmission in der Zukunftsschau Jesu 1959), and later in his Witness to the World (1980) and in an article in Theologia Evangelica (1980), Bosch had a negative evaluation of the apocalyptic. In Transforming Mission, the apocalyptic played a limited, positive, role, but Bosch restricted it to his study of Paul's mission theology (Bosch 1991:173-192; König 1990:21-24; Wielenga 2002: 111-112). Bosch did not explore the considerable apocalyptic contributions of other New Testament texts, such as Matthew 24 or Mark 13, as some of his colleagues at the time indeed attempted (e.g. Muddiman 2014; Wielenga 2002).

Some local theologians hinted at the exciting contribution to missiology that may stem from a renewed interest in apocalyptic thinking. Adrio König, whilst expressing his admiration and appreciation for Bosch's work, challenged him to reconsider the apocalyptic in his missiology (König 1990). Wielenga (2002) developed an apocalyptic missiology from the gospel of Matthew and Botha (2005) turned to the Book of Revelations for missiological direction in addressing South African challenges.

Seeing that we once again live in an 'apocalyptic time', I attempt to explore the contribution that apocalyptic theology

1.Warren seems to distinguish between apocalyptic which he calls 'second Adventism', that predicts that the catastrophic end of the world is at hand, and Adventism', that predicts that the catastrophic end of the world is at hand, and eschatology or his 'theology of hope' as a Christian re thense to it (Meiring 1968 : 42-43). In this research, I make use of different definitions for both (as I will show later in the article). Nevertheless, I do believe that Warren's concern falls within $\mathrm{my}$ description of apocalyptic. may make to current missiology - to set an apocalyptic agenda for mission - using a qualitative literature study. I will firstly define apocalyptic and distinguish between eschatology and apocalyptic, as these often seem to be used inconsistently, sometimes as synonyms and other times as opposites, or as consecutive stages. I will then describe the main features of apocalyptic, drawing together the insights of various theologians. Finally, I will propose what an apocalyptic agenda for a mission might entail. I hope to contribute to missiological thinking by arguing for a new look at apocalyptic, by recording the insights of earlier apocalyptic missiologists and suggesting some new dimensions for missiology in South Africa.

\section{What is apocalyptic?}

'Apocalyptic', according to the lexicon, is mostly used as an adjective to describe a catastrophic event or the destruction of the world; it is also used as an interchangeable synonym for eschatology (Lexico.com).

However, describing more closely what the term entails is not an easy task. 'Apocalyptic' is, as Tuckett (2014) points out, used in different ways:

How to define what is an 'apocalypse', or what can or should count as 'apocalyptic', whether it is sensible to talk about 'apocalypticism', whether there are genuinely 'apocalyptic ideas', or 'apocalyptic ways of speaking', the relationship (if any) between 'apocalyptic' and eschatology, are all issues which have no clear, unambiguous answers. (p. 155)

Le Roux (1978:41) makes an interesting distinction between 'the end of days' and 'the last days'. He explains that 'the end of days' refers to the end of the world, whilst 'the last days' refers to the time that precedes the end. This helps to differentiate between eschatology (the end of days) and apocalyptic (the last days) which 'does not refer to a specific time in history because each generation experienced his own time as the last of the days'.

In his monograph, Rowland offered a clear definition of apocalyptic and made a useful distinction between apocalyptic and eschatology. He described apocalyptic as an expression of religion, based on the revelation of divine secrets - mediated through dreams, visions or special revelations - that provide meaning and afford significance to us as humans (Rowland 1982:21, also Morray-Jones 2014:10). These secrets may be eschatological but are not exclusively so. They are meant to provide the real meaning of contemporary events in history, disclosing immanent changes to the current situation, and offer believers a new way of looking at the world and God.

Eschatology, in turn, is characterised by Rowland as the description of the end. Whilst eschatology may at times be part of apocalyptic, it is not a key feature of apocalyptic. Eschatology may differ from apocalyptic when it looks towards the fulfilment of God's promises within history, whereas apocalyptic emphasises a supernatural intervention beyond time (1982:25-26). 
Not everybody accepts Rowland's description. Wilken (1984:231) has reservations about his distinction between apocalyptic and eschatology, whilst Collins (1984:465-467) questions the special revelations reserved for apocalyptic. Nevertheless, I agree with Morray-Jones (2014:10) that Rowland offers a corrective to the widely held view that apocalyptic is primarily concerned with eschatological prediction. The apocalyptic writers' interest, he recounts, was much broader and also included the hidden processes of creation, the secret workings of the universe, astronomical and calendric teachings, the past course of human history, the heavenly world and its inhabitants and the vision of the enthroned divine Glory.

Rowland (1982) recalls the rabbinic proscription of unauthorised engagement with the hidden dimensions of creation and God's appearance, and the accompanying warning against involvement in these matters. According to the Talmud (M. $\operatorname{Hg} 2: 1)$ :

Whosoever gives his mind to four things, it were better for him if he had not come into the world - what is above, what is beneath, what was beforetime, and what will be hereafter. (p. 75)

This, according to Rowland, is exactly what the apocalyptic writers set out to do: understanding above and below, the powers of good and evil - that gives insight into before and after, the past and the future (Rowland 1982:75).

Similarly, Rowland explains apocalyptic by distinguishing two complimentary dimensional axes: one vertical (abovebelow) and the other horizontal (before-hereafter). In some apocalyptic writings of ascent and descent, the vertical axis is emphasised, whilst in eschatological predictions of divine intervention and judgement, the temporal, horizontal, axis dominates. An apocalyptic seer, then, understands the historical narrative in relation to the vertical axis of cosmic conflict (Morray-Jones 2014:12).

\section{Elements of apocalyptic}

When characterising apocalyptic, it is important to remember that there are many diverse elements in these writings. Lombard (1978:21) cautions that 'there is definitely no such thing as "the" apocalyptic, as if apocalyptic exists as a simplistic phenomenon without nuances of form and content'. The different apocalyptic texts display different forms, contents and views.

In addition, whilst many Old Testament scholars locate the apocalyptic within the prophetic tradition, others follow Von Rad's view that it should rather be seen as a late-type of wisdom literature (Morray-Jones 2014:14; Rowland 1982:245; Von Rad 1965:301-315). Le Roux (1978:56) contends that the apocalyptic writers did not set out to supersede the prophets, but rather to be 'the continuation or outcome of prophesy. Apocalyptic literature was prophecy in a new idiom'). This leads to both a continuity and discontinuity between prophetism and apocalyptic (Lombard 1978:23). In contrast, Von Rad (1965:306) famously claimed the wisdom literature to be 'the "nerve centre" of apocalyptic literature'. MorrayJones (2014:14) further demonstrates that apocalyptic offers mantic ${ }^{2}$ wisdom. A third view is that apocalyptic originated precisely because of the absence of prophetism and wisdom literature (König 1990:26). Barton (2014:47) adds that it may well be that apocalyptic's ethics lead to its divergence from other Jewish writings. Early Jewish apocalyptic also developed (or progressed) with time, and Christian apocalyptic, in turn, modified its Jewish precursor (König 1990:27-28, Lombard 1978:27, 30).

Despite the disagreement about the origin of apocalyptic and the differences in form and content, there are still more that the various apocalyptic writings have in common. König (1990:26-27) proposed five elements that seem to characterise the apocalyptic. I will use, and add to, his framework.

\section{Supernaturalness}

The language of the apocalyptic and the events described are supernatural, rather than natural. König (1990) explains:

In contrast to the ordinary, historical, familiar images of the prophets (peace, prosperity, or war, plague, drought) apocalyptic works with supernatural, extraordinary, rather unimaginable images and catastrophic experiences that will disturb the entire creation. (p. 26)

Apocalyptic starts off in a transcendental realm where promised saving blessings are already pre-existent in the world above, from where it will descend to earth (Ekem 2017:3; Von Rad 1965:302). When these events occur, the apocalyptic events may be without precedent and unheard of. Both Jewish and Christian apocalyptic, for example, foresees the general resurrection of many or all of the dead, and a dramatic ending of the world (König 1990:260).

The apocalyptic is often beyond normal time or removed from the historical time: 'hope and life lie beyond our history' (Lombard 1978:26). In contrast to prophetism that plays out in specific historical setting and within the salvation history scheme, apocalyptic does not refer back to the great saving events in the history of God's people, but to events that will take place somewhere in an obscure future: 'a day an hour that no one knows' (Mt 24:36). As mentioned above, it becomes true for every generation, experiencing the last days in their time and context (Le Roux 1978:41, 55; Von Rad 1965:303).

Supernatural events may be the only hope when pessimism prevails. Apocalyptic literature's view of history is pessimistic in the extreme: total despair of the history of the world and the prospects for humankind, and the world moving towards destruction (Lombard 1978:25; Von Rad 1965:305). The pessimism may be as a result of the experience of the relative absence of God, the destruction wrought by sin and Satan, and of very real suffering, hardship and misery (Allen 2000:387-390; Barton 2014:48; Le Roux 1978:41-47).

2.Mantic wisdom is inspirational wisdom which can be distinguished from proverbial wisdom (Morray-Jones 2014:14). 
It follows that the apocalyptic outcome will not arrive through any human agency, and eliminates humans' participation in God's programme (Le Roux 1978:55; Lombard 1978:26). God is the One that takes control and acts decisively. Whilst the Old Testament is by and large optimistic about the human capacity for ethical behaviour, the apocalyptic view had no hope for human endeavours (Barton 2014:47-49).

Likewise, apocalyptic knowledge is not accessible through ordinary reason, but rather revealed through dreams or oracles by which God discloses inaccessible mysteries to the apocalyptic visionaries (Ekem 2017:3; Lombard 1978:22).

Another aspect of the supernaturalness has to do with secret language and secret-keeping in apocalyptic. Whilst apocalyptic seers may understand or may have received a revelation on the unfolding of events, they keep it absolutely secret, perhaps because they themselves do not fully understand (Von Rad 1965:302). Only the initiated can understand or calculate the events and decipher the symbolic images (Allen 2000:388; Lombard 1978:28; Von Rad 1965:302). All is veiled in supernatural mystery.

\section{Historical dualism}

Apocalyptic divides world history into exact periods or aeons, with the most basic division being the sharp distinction between the present evil age and the unimaginable good and beautiful age to come (Ekem 2017:3; König 1990:26; Le Roux 1978:41; Von Rad 1965:302; Wielenga 2002:112).

According to 2 Esdras 7:50, '[ $t$ ]he Most High has made not one world but two'. This dualism makes no provision for the recovery of history or humankind, but rather envisions one period coming to a complete catastrophic end after which the second era starts. Interestingly, there are also examples of the two aeons being the lost golden past (primordial time), and the corrupted present (Brueggemann 2000:153; Chester 2014:333-335; Lombard 1978:25, 28; Tanner 2000:226-233; Vanderkamm 2014:78).

Apocalyptic holds the conviction that God has complete control over history and will accomplish his goal. He (Le Roux 1978):

$[W]$ ill not leave the faithful in the lurch and therefore he will surely bring to an end the course of this history so that the sinners can be punished and the faithful rewarded. (p. 53)

Then God will bring about the dawning of the new, wonderful age.

Consequently, the dualism is also exhibited in descriptions of newness - a new creation, a new earth, the new people of God and new disclosures. Apocalyptic is not only concerned with the end, but also with what lies beyond it (Allen 2000:389; Botha 2005:320; Brueggemann 2000:150-151; Lombard 1978:25; Tuckett 2014:156). Furthermore, the new disclosures were often thought to be new revelations from
God that superseded, rather than just restated, other revelations. These were God's 'final revelations' (Lombard 1978:22).

In Christian apocalyptic, the dualism was modified. Whilst Jewish apocalyptic accepted a clear division between the present age and the age to come, this negative view of the present age was changed by the resurrection of Jesus, the outpouring of the Holy Spirit and Jesus' frequent exorcisms. These all proclaimed 'that in Jesus the kingdom of God had already appeared' (König 1990:28).

\section{Immanence}

The apocalyptic tradition reveals that the end of the present age, and the coming of the new age, is near. As God will bring his judgement to the world, the apocalyptic seers called their listeners to choose, now, against the sins of the last days. Thus, the immanence manifested an urgency to heed the apocalyptic warning and a call to make the right choices in the light of these insights: '[e]verything is determined now, and each one stands under the obligation to choose now; now he must decide whether he chooses life or death' (Le Roux 1978:50, see also Wielenga 2002:112).

In apocalyptic, making the right choice now usually demands that believers make the right ethical choices. By following the ethical guidelines offered in apocalyptic, they take God's side against the evil world, as explained later in the section 'Options for humans'.

The message that Jesus rose from the dead already introduced the end time for Christian apocalyptics. The coming age was no longer restricted to the future, but had already been inaugurated, and was available to Christ's followers (Bosch 1991:178-181; Botha 2005:319; Dillistone 1948:71-74; König 1990:28).

Wielenga (2002:116-118), however, argues that because many of the early Christians expected the second coming as the fulfilment of the apocalyptic promises, the delay, or failure, of this to materialise had to be dealt with. Some saw the fulfilment in the collection for Jerusalem, the Gentiles carrying gifts to the Jerusalem (Bosch 1991:145-146), and others in the outpouring of the Holy Spirit as narrated in Acts. Wielenga proposes another possibility - as we will explore in the next section.

\section{Universal cosmic expectation}

Apocalyptic focusses on all people and the entire world. Whilst the prophets spoke to the people of Israel and God's dealings with the nations were understood to be related to Israel, the apocalyptic message proclaimed a new earth for all (König 1990:27; see also Wielenga 2002:112).

In Christian apocalyptic, the universal message is even stronger. Bosch (1991:35-36) argues that Jesus' ministry exceeded that of the prophets and preachers of his time, to 
include also the Gentiles, and so did his followers (Wielenga 2002:116). Wielenga makes the case that mission to the rest of the world was 'crisis management'. The early Christians expected the immanent return of Christ, and when that failed to happen they shifted their Jerusalem-centred, centripetal mission towards a Gentile-centred, centrifugal mission (Wielenga 2002:118).

The style and language of the apocalyptic also have a universal application. It frequently contains symbolic and mystical images. Whilst these symbols were mostly derived from the Old Testament prophets (Brueggemann 2000:149; Lombard 1978:28), I would venture that the symbolic nature also made it more accessible and applicable for a more universal audience. Thus, Allen (2000:392) sees apocalyptic language as 're-mythologising the typical (cultic) myths' to address universal longing and suffering. In the current South African context, Botha (2005:326) utilises the symbolic, metaphorical language of John's Revelation to challenge neo-liberal capitalism.

\section{Victory}

Apocalyptic envisions a universal and final victory where God will completely destroy the Evil One who is responsible for the present chaos. 'It introduces the eternal glory where there will never again be any resistance to God or any threat to his children' (Ekem 2017:3; König 1990:27, see also Tuckett 2014:164).

This can also be seen in the determinism of apocalyptic. It is believed that the final events were determined far back in the past, and now history rapidly and irrevocably moves to the end of time through calamities in nature and amongst nations, to an inevitable culmination point determined by God. The 'signs of the times' signal and guarantee this victory (Allen 2000:388; Lombard 1978:25-26; Von Rad 1965:302).

Christian apocalyptic also recognises the signs and wonders as harbingers of God's final victory. Jesus' victory over death is a final, once and for all victory over sin and darkness (Tuckett 2014:164-165). In addition, the victory is often less spectacular and fulfilled in new, different ways (König 1990):

Nothing is seen on the day of Pentecost of the apocalyptic images of bloodshed, fire and clouds of smoke (Joel 2:30), not because less happened than was prophesied (in fact much more happened in Acts 2 than a gruesome battle), but because apocalyptic prophesy can be fulfilled in a more ordinary way and less supernaturally. (p. 29)

\section{An apocalyptic agenda for missiology}

What does apocalyptic offer missiology? Apocalyptic theology, as we have seen, arose in specific contexts where other types of theology could not adequately address the experiences of believers, and failed to provide a way forward. It spoke about the experience of the relative absence of God, the presence of sin and Satan and the terrible suffering of
God's people. In times of total despair, the apocalyptic writers re-interpreted the traditions of their predecessors for their times - often using pseudonyms - and adapting the words of the prophets or the wisdom of the sages of previous generations (Le Roux 1978:41-47; Lombard 1978:25, 27, 37).

It is then no wonder that not only eschatology, but also apocalyptic theology had featured strongly during and after the Second World War, giving hope to a disillusioned world. The ensuing decades of the Cold War sustained the interest in the apocalyptic mode. Although the apocalyptic voice has subsequently quieted down, our current crisis and context may well benefit from the visions of the apocalyptic seers.

I suggest that apocalyptic theology may enrich missiology in the following ways.

\section{Speaking about God}

Despite, or probably because of, the felt absence of God, apocalyptic theology insists on a transcendent, almighty, impenetrable and supernatural concept of God. God is in complete control of all world events and is rolling out his predetermined plan for the world. Humans have no role to play in the unfolding of God's intervention; the future does not depend on human action. Brueggemann (2000:149) hails it as a return to a theocentric worldview.

Apocalyptic seers, however, are able to lift the veil, to see or to know what is taking place because of direct revelations, trances and insights that God gives to the faithful. They understand (some of) the secret plans of God and comfort others with this knowledge. Ultimately, God is beyond our understanding, or our judging, even beyond good and evil (Allen 2000:393).

König (1990) argues that a more supernatural understanding of God may be timely. Although many people expected religion to disappear, human 'need for the mystical and (humankind's) enslavement to supra-human powers and power structures, have once again come to the fore' (König 1990:30). That is why both Allan Boesak and Nico Botha are fond of referring to the Book of Revelation to expose racism and neo-liberal capitalism in South Africa (Botha 2005:316, 325).

The church can with confidence proclaim that salvation is not something that humans can achieve, and that the solution to world-wide problems is not simply human, but requires the supernatural, transcendental message of the gospel (Bosch 1991:500; König 1990:30).

\section{Options for humans}

What is left for humans when God is all-powerful? Interestingly, apocalyptic expects a definite response from humans. With an almost tangible urgency, the apocalyptic writers call on their listeners to take a side, to choose for life or death (Le Roux 1978:50; Wielenga 2002:112). 
Apocalyptic calls on human beings to follow God in changing the world, fighting for social justice, speaking truth to power - 'forthtelling' as Botha (2005:323-324) coins it. It demands non-collaboration with the worldly powers and unjust structures and may also require sacrifice (Botha 2005:327-328)

In addition, apocalyptic offers humans an ethic to survive, even prosper, despite the evil powers that govern the world. Morray-Jones typifies this ethic as 'mantic' or inspirational wisdom which can be distinguished from proverbial wisdom. In mantic wisdom, the apocalyptic hero, such as Daniel and his friends, offers an example for others to live by (MorrayJones 2014:14).

Apocalyptic ethics also display a protreptic tendency, where believers are called to a radical commitment to their faith, to be willing to be distinct from the world - in contrast to a paraenetic ethic which suggests a good life within a community on an ongoing basis (Barton 2014:38). Believers must be seen to be and do differently.

The third characteristic of apocalyptic ethics is complete submission to God. All are called to submit - both the faithful and the evil princes of the world. Apocalyptic believers are, according to Barton (2014:50), quietists who are saved in returning to and resting in God: ' ... in quietness and in trust shall be your strength' (Is 30:15). This quietness would be effective because God was on their side (Barton 2014:51).

It seems that an apocalyptic agenda for mission corroborates the understanding of mission as Missio Dei and/or Missio Ecclesiae and adds a further dimension for the church's participation in God's revelation by providing new ways to engage with the world: echoing God's prophetic call to justice, and teaching a trusting, distinct, holy, ethic to a complicated world. In addition, as apocalyptic has always been a clarion call, intended to jolt believers into action, it may restore a sense of urgency in mission.

\section{A different dream}

The apocalyptic future is cosmic, universal and open. Whilst the Old Testament prophets also mentioned the nations and admitted them as part of God's activity and future, they still envisaged the nations coming to Jerusalem. The apocalyptic writers severed the ties with Jerusalem; God's saving and judging work would go out to all corners of the earth; world history is united (Von Rad 1965:304). Likewise, the early Christians, as Wielenga (2002:115) has shown, turned from a centripetal calling centred on Jerusalem to a centrifugal mission to all the world.

The universalism of apocalyptic can be seen in the letters of Paul. There is some debate amongst theologians whether Paul was universalist or rather particularist; Christopher Tuckett shows that wherever Paul seems to be most universalist, for example, Romans 5 or 1 Corinthians 15 , he always employs apocalyptic language and images to make his case (Tuckett 2014:156-164, see also Collins 2014:141).

Both the eschatological end and the new creation apply to all humans, and the new apocalyptic world even transcends creation by the vision that chaos is completely overcome by God and all are made new (Chester 2014:333, 346; Wielenga 2002:112, 114).

Whilst Jewish apocalyptic arose in specific contexts and crises, the visions were not bound to specific places or times. In contrast, once again, with the prophets, the apocalyptic visions were ahistorical (Von Rad 1965:303) and the apocalyptic eschatology was also dehistorised (Lombard 1978:26) and thus applicable to more than only one time or group.

This possibility was further established when Christian apocalyptic authors confessed that the kingdom of God had already appeared. The dualistic distinction between the aeons blurred, opening up to different appropriations of our time. Not everything in the world is bad, nor the entire world in chaos, or under the sway of the Evil One. '(A)mid much sin, chaos and suffering, Christians may expect to find signs of the work of God through his Spirit in the world (König 1990:29-30).

The symbolic, metaphorical style of the apocalyptic opened it up for universal use. The images could be found again and again and the recurring patterns - of a golden past, an evil, sinful present and a return to bliss - could be recognised where they manifested (Vanderkamm 2014:73-86).

In John Mbiti's study on eschatology in the African context, he suggests that the apocalyptic view of time (which he explored looking at Revelations 21) may correct the linear, future, eschatology of the West, and better speak about the cyclical dimension of time espoused in Africa (cited in Ekem 2017:9-10). The universal dream of apocalyptic does just that.

The universal expectation further includes not only all peoples and ages, but also every part of life on earth, making it extremely meaningful and necessary in the present time. König (1990) emphasises that the gospel is intended for the entire human race, and involves our total existence, our bodies as well as our souls; it applies to pollution, overpopulation and the exploitation of energy resources (König 1990:30). Ekem (2017) summarises:

The apocalyptic author is drawing attention to a radical renewal of creation by a Sovereign God who is not limited by time and space and whose rescue package embraces the entire ecology, human beings inclusive. (p. 14)

\section{Understanding our time}

The apocalyptic gives us a new understanding of ourselves and our times. To begin with, it offers believers a new identity in difficult times. Le Roux records that the Jewish apocalyptic communities not only rebelled against mainstream society 
but also suffered from an identity crisis as a result of their distancing themselves from others. Apocalyptic provided a new group-identity built on the hope that God would appear and establish a new world (Le Roux 1978:55). Apocalyptic ethics, in addition, provided identity markers to these communities (Barton 2014:38).

The apocalyptic vision was thus a source of comfort and consolation in the midst of sin, suffering and pessimism (Le Roux 1978:55; Lombard 1978:34). Allen (2000:389) argues that this apocalyptic comfort is also needed and useful today in dealing with the present chaos. Instead of trying to escape reality, apocalyptic provides 'a complete faith system worked out in fantastic imagery that provides a very present hope in a hopeless present' (Allen 2000:389).

Allen continues that deficiencies in Jewish and Christian religious systems gave rise to apocalyptic's new religious language, for example, in the absence of prophetic voices, the apocalyptic countered the rabbinic legalism after the exile. Similarly, apocalyptic offers a new way to understand, or deal with, God in times of utter suffering, grief or oppression, in the 'wilderness land' where traditional belief does not make sense any more. Allen (2000) concludes:

In the apocalyptic literature, God is not so good. God destroys, causes suffering, brings on plagues, and interrupts the heavens. But the reader of apocalyptic understands that such a devastating God does so in order that good may eventually triumph. Thus, one purpose of apocalyptic language is to reframe the 'good' God revered in weekly worship rituals into the picture of present suffering. (p. 393)

Ekem (2017:12) agrees that apocalyptic visions long served as 'beacons of hope and comfort for traumatised families' the apocalyptic texts being sung at funerals, and used as inspiration in the midst of political oppression, exploitation, marginalisation, and intimidation.

The apocalyptic hope speaks about our time. Moltmann argues that whilst most of our theology has been centred on the Greek philosophies concerning the proof of God, it is eschatology, and not theological proofs, that gives us hope in a crisis (cited in Allen 2000:390-391):

Totally without hope one cannot live. To live without hope is to cease to live. Hell is hopelessness. It is no accident that above the entrance to Dante's hell is the inscription: 'Leave behind all hope, you who enter here'. (Moltmann 1993:20)

Hanson (cited in Allen 2000) concludes that apocalyptic writings:

... [G]rew out of the courage to stare into the abyss on the edge of which an entire civilization tottered, and the willingness to describe what the fantasy of faith enabled the human eye to glimpse beyond the tragedy. (p. 394)

One of the embarrassments of the Christian faith is the delay of the parousia. Whilst Christians expected the immanent return of Christ, this has not yet happened. Apocalyptic's immanent expectation has received extensive consideration and discussion (Bosch 1991; Wielenga 2002), but König adds (in my view) a stimulating answer. He argues that the fulfilment of God's promises, of God being near to his people, has more to do with the covenantal relationship, than with a temporal description. The parousia is near because God is near (1990:30-32). Tanner (2000:231) similarly explores eternal life, associated with the apocalyptic, as a present reality, and Moltmann (2005:158) asks, '[w] hy should Christ "come again" when, after all, he has not gone away, when we sense his presence everywhere?'.

In addition, when Christians adapted the Jewish apocalyptic, they saw the first coming and the resurrection of Christ as the decisive point in history. König (1990:32) says that '[s]alvation has entered the present because Christ is God's creation goal. The coming kingdom has already come. The goal that is to be realised, has already been realised'. The apocalyptic hope of an immanent end may then describe a present world in which God is experienced as near, and Christ's work is accomplished.

This echoes the central message of the gospel as is also proclaimed in mission: 'The time has come', he said. 'The kingdom of God has come near. Repent and believe the good news!' (Mk1:15)

Botha (2005:327) deducts from the Book of Revelations that 'a prophetic spirituality is a spirituality of hope'; I would add that an apocalyptic spirituality, apocalyptic language and theology, similarly gives hope to a broken, disillusioned world.

\section{Conclusion}

As indicated earlier, over the past decades, missiology benefited greatly by giving serious attention to eschatology. It is my contention that missiology, in our time and circumstance, will similarly benefit from revisiting the apocalyptic writings of the Old Testament and New Testament. Apocalyptic may also be used to develop a 'theology of hope' as well as a 'missiology of hope' something that the church and mission are in dire need of. The apocalyptic visions provide the church with new ways of understanding herself and offer an original and appropriate way to witness God in our present apocalypse.

In attempting this, we, South Africans, will find ourselves in the company of the great African theologian, Bishop Quodvultdeus of Carthage, who in the 5th century turned to apocalyptic theology when suffering at the hands of Vandals (Gould 2003:811).

Miller (2000:169) adds that the final gift of apocalyptic is joy! This is exactly what missiology and mission should do: sing a new song of joy to the Lord (Morray-Jones 2014):

Suddenly the Thing happened, and, as everybody knows, it cannot be described in words. The Bible phrase, 'I saw the heavens open' seems as good as any if not taken literally. I remember saying to myself, in awe and rapture, 'So it's like this: now I know what heaven is like, now I know what they mean in church'. (p. 10) 


\section{Acknowledgements Competing interests}

The author declares that he has no financial or personal relationships that may have inappropriately influenced him in writing this article.

\section{Author's contributions}

I declare that I am the sole author of this research article.

\section{Ethical consideration}

This article followed all ethical standards for a research without direct contact with human or animal subjects.

\section{Funding information}

This research received no specific grant from any funding agency in the public, commercial or not-for-profit sectors.

\section{Data availability statement}

Data sharing is not applicable to this article as no new data were created or analysed in this study.

\section{Disclaimer}

The views and opinions expressed in this article are those of the author and do not necessarily reflect the official policy or position of any affiliated agency of the author.

\section{References}

Allen, J.T., 2000, 'God-talk as apocalyptic', The Journal for Pastoral Care 54(4), 387-404. https://doi.org/10.1177/002234090005400402

Barton, J., 2014, 'Ethics in apocalyptic', in C. Rowland (ed.), Revealed wisdom: Studies in apocalyptic in honour of Christopher Rowland, pp. 37-51, Brill, Leiden.

Bosch, D.J., 1991, Transforming mission - Paradigm shifts in the theology of mission, Orbis, New York, NY.

Botha, N., 2005, 'Mission as prophecy: "Reading the apocalypse as forthtelling rather than foretelling"', Missionalia 33(2), 315-328.

Brueggemann, W., 2000, 'Faith at the Nullpunkt', in J. Polkinghorne \& M. Welker (eds.), The end of the world and the ends of God - Science and theology on eschatology, pp. 143-154, Trinity Press, Harrisburg, PA.

Chester, A., 2014, 'Chaos and new creation', in C. Rowland (ed.), Revealed wisdom: Studies in apocalyptic in honour of Christopher Rowland, pp. 333-347, Brill, Leiden.

Collins, A.Y., 1984, 'Review of the open heaven: A study of apocalyptic in Judaism and early Christianity, Christopher Rowland', Journal of Biblical Literature 103(3), 465-467. https://doi.org/10.2307/3260801

Collins, A.Y., 2014, 'The transformation of Paul's apocalyptic ideas in the first two centuries', in C. Rowland (ed.), Revealed wisdom: Studies in apocalyptic in honour of Christopher Rowland, pp. 138-154, Brill, Leiden.
'Covid-19 raises the risks of violent conflict', The Economist, 18 June 2020, viewed 21 July 2020, from https://www.economist.com/international/2020/06/18/ covid-19-raises-the-risks-of-violent-conflict.

Dillistone, F.W., 1948, 'The hope set before us', in M. Warren (ed.), The triumph of God, pp. 65-90, Longmans, London.

Ekem, J.D., 2017, Interpreting texts from an African perspective: A case study of revelation 21:14 ..., SBL Paper, Trinity Theological Seminary, Accra.

Gould, G., 2003, 'Review of Quodvultdeus of Carthage. The apocalyptic theology of a roman African in exile, Daniel van Slyke', The Journal of Theological Studies 55(2), 811. https://doi.org/10.1093/jts/55.2.811

Kettley, S., 2020, 'Coronavirus: Fears fourth seal of apocalypse broken as Bible warning of pestilence unfolds', The Express, 20 April 2020, viewed 21 July 2020, from https://www.express.co.uk/news/weird/1244611/Coronavirus-fourth-sealapocalypse-Bible-Book-of-Revelation-pestilence-coronavirus.

König, A., 1990, 'Apocalyptic, theology, missiology', in J.N.J. Kritzinger \& W.A. Saayman (eds.), Mission in creative tension: A dialogue with David Bosch, pp. 20-33, SAMS, Pretoria.

Le Roux, J.H., 1978, 'The "last days" in apocalyptic perspective', Neotestamentica 12, $41-74$.

Lombard, H.A., 1978, 'The character, epoch (period), origins (motives), and methods of Jewish apocalyptic', Neotestamentica 12, 20-40.

Meiring, P.G.J., 1968, 'Max Warren as Sendingwetenskaplike', D D thesis, University of Pretoria.

Miller, P.D., 2000, 'Jugdement and joy', in J. Polkinghorne \& M. Welker (eds.), The end of the world and the ends of God - Science and theology on eschatology, pp. 153-170, Trinity Press, Harrisburg, PA.

Moltmann, J., 1993, Theology of hope, Fortress Press, Minneapolis, MN, viewed 21 August 2020, from https://www.religion-online.org/cgi-bin/relsearchd.dll/ showbook?item_id=2071.

Moltmann, J., 2005, 'The blessing of hope: The theology of hope and the full gospel of life', Journal of Pentecostal Theology 13(2), 147-161. https://doi.org/10.1177/ 0966736905053242

Morray-Jones, C.R.A., 2014, 'The opening of heaven in the book of job', in C. Rowland (ed.), Revealed wisdom: Studies in apocalyptic in honour of Christopher Rowland, pp. 10-36, BRILL, Leiden.

Muddiman, J., 2014, 'The reader of Mark 13:14b as the (re-)interpreter op apocayptic', in C. Rowland (ed.), Revealed wisdom: Studies in apocalyptic in honour of Christopher Rowland, pp. 170-182, Brill, Leiden.

Okereke, C. \& Nielsen, K., 2020, 'The problem with predicting coronavirus apocalypse in Africa - Claims that Africa will be hit the worst by the pandemic ignore African epidemiological know-how and action', Al Jazeera, 07 May 2020, viewed 21 July 2020, from https://www.aljazeera.com/indepth/opinion/problem-predictingcoronavirus-apocalypse-africa-200505103847843.html.

Olivier, B., 2020, 'Covid-19: Lessons from the zombie apocalypse', Mail \& Guardian 25 March 2020, viewed 21 July 2020, from https://mg.co.za/article/2020-03-25covid-19-lessons-from-the-zombie-apocalypse/.

Rowland, C., 1982, The open heaven - A study of apocayptic in Judaism and early Christianity, SPCK, London.

Tanner, K., 2000, 'Eschatology without a future?', in J. Polkinghorne \& M. Welker (eds.), The end of the world and the Ends of God - Science and theology on eschatology, pp. 222-237, Trinity Press, Harrisburg, PA.

Tuckett, C., 2014, 'Paul and universalism', in C. Rowland (ed.), Revealed wisdom Studies in apocalyptic in honour of Christopher Rowland, pp. 155-169, BRILL, Leiden.

Vanderkamm, J.C., 2014, 'Psalm 90 and Isaiah 65 and Jubilees 23', in C. Rowland (ed.), Revealed wisdom: Studies in apocalyptic in honour of Christopher Rowland pp. 73-86, Brill, Leiden.

Von Rad, G., 1965, Old Testament theology volume two, SCM Press, London.

Warren, M., 1947, The truth of vision. A study in the nature of Christian hope, Canterbury Press, London.

Wielenga, B., 2002, 'Mission and the apocalyptic - A perspective from Matthew', International Review of Mission 91(360), 111-119. https://doi.org/10.1111/j. 1758-6631.2002.tb00333.x

Wilken, R.L., 1984, 'Review of the open heaven: A study of apocalyptic in Judaism and early Christianity, Christopher Rowland', Church History 53(2), 231. https://doi. org $/ 10.2307 / 3165358$ 